\title{
Different silicon forms sinalize an input of urbanized river and indicate the presence of phytoplankton with silicon structures in the tropical coastal area of Recife (PE-Brazil)
}

\author{
Ana Teresa Cordeiro Cid Bastos ${ }^{1}$, Elisabete de Santis Braga ${ }^{1 *}$
}

\author{
${ }^{1}$ Laboratory of Nutrients, Micronutrients and Traces in oceans (LABNUT) - Instituto Oceanográfico da Universidade de São Paulo \\ (Praça do Oceanopgráfico, 191 - Butantã - SP - 05508120 - Brazil) \\ *Corresponding author: edsbraga@usp.br
}

\begin{abstract}
The urbanized areas mark its presence in the hydrological systems with some biogeochemical signs including silicon inputs. Natural influence of leaching and erosion is done by silicate contribution and sometimes, the agriculturally soil contains microphytoliths and contributes with biogenic silica. Once in the hydrological system, the silicon can integrate the biogeochemical cycles showing a balance or not between inorganic and biological forms that reveals a tendency of processes that occur in each sector of the estuarine-marine interface. This study aims to evaluate the impact of a heavily polluted/urbanized river, whose input can be evidenced by the contribution of different forms of silicon that can evidence the terrestrial contribution, erosion process, the presence of phytoplankton species with siliceous structures, mainly associated to diatoms and also, to study the river plume spreading on the coastal area by undertaking silicon profiles in the region adjacent to the river mouth. The coastal region of Recife is under influence of fluvial inputs from Capibaribe and Beberibe rivers verified by observed low salinity (min. 33.93). The distribution of silicon forms showed sectorial variation, and the maximum values were dissimilar. Dissolved silicate reached $14.40 \mu \mathrm{mol} \mathrm{L}^{-1}$, lithogenic silicon (LSi) maximum of $25.76 \mu \mathrm{mol} \mathrm{L}^{-1}$ and biogenic silica (BSi) reaching $7.39 \mu \mathrm{mol} \mathrm{L^{-1 }}$ near the river mouth toward the sea, evidencing the river influence coming from the west, achieving the port barrier at the end and propagating in the sea toward northeast. Due to higher nutrient availability in the stations nearest to the coast, primary production was encouraged with evidencing by high values of chlorophyll- $a$ associated to silicate $(\mathrm{r}=0.71)$ and to $\mathrm{BSi}$ $(r=0.44)$. In the stations more distant to the coast, the forms of silicon showed very low concentrations and $\mathrm{BSi}$ / Chlorophyll- $a$ showed negative correlation associated with chlorophyll- $a$ concentrations evidencing the participation of non-silicon actors in the primary production in medium depth in oligotrophic tropical waters.
\end{abstract}

Descriptors: Lithogenic silica, Biogenic silica, Silicate, Biogeochemistry, Tropical region, Polluted estuary.

\section{Resumo}

As áreas urbanizadas marcam sua presença nos sistemas hidrológicos com alguns sinais biogeoquímicos, incluindo entradas de silício. A influência natural da lixiviação e erosão é feita por contribuição de silicato e, às vezes, o solo agrícola possui microfilóticos e contribui com sílica biogênica. Uma vez no sistema hidrológico, o silício pode integrar os ciclos biogeoquímicos mostrando um equilíbrio ou não entre formas inorgânicas e biológicas que revela uma tendência de processos que ocorrem em cada setor da interface estuarino-marinha. Este estudo tem como objetivo avaliar o impacto de um rio fortemente poluído/urbanizado, cujo aporte pode ser evidenciado por diferentes formas de silício que podem marcar o aporte terrestre, processo de erosão, a presença de espécies de fitoplâncton com estruturas silicosas, principalmente associada a diatomáceas e, também, estudar a pluma do rio espalhando-se na área costeira realizando perfis de silício na região adjacente à foz do rio. A região costeira do Recife está sob influência dos insumos fluviais dos rios Capibaribe e Beberibe verificados pela baixa salinidade observada (mínimo 33,93). A distribuição de formas de silício mostrou variação setorial e os valores máximos foram distintos. O silicato dissolvido atingiu $14,40 \mu \mathrm{mol} \mathrm{L}{ }^{-1}$, silício litogênico (LSi) no máximo de $25,76 \mu \mathrm{mol} \mathrm{L}-1$ e sílica biogênica (BSi) atingindo 7,39 $\mu \mathrm{mol} \mathrm{L} \mathrm{L}^{-1}$ perto da foz do rio em direção ao mar, evidenciando a influência do rio vindo do oeste, alcançando a barreira portuária no final e se propagando no mar em direção ao nordeste. Devido à maior disponibilidade de nutrientes nas estações mais próximas da costa, a produção primária foi incentivada com a evidência de altos valores de clorofila- $a$ associados ao silicato dissolvido $(\mathrm{r}=0.71)$ e ao $\mathrm{SiB}(\mathrm{r}=0.44)$. Nas estações mais distantes da costa, as formas de silício apresentaram concentrações muito baixas e BSi/Clorofila- $a$ mostrou correlação negativa associada a concentrações de clorofila- $a$, evidenciando a participação de atores não silicosos na produção primária em profundidade média em águas tropicais oligotróficas.

Descritores: Silício litogênico, Sílica biogênica, Silicato, Biogeoquímica, Região tropical, Estuário poluído. 


\section{INTRODUCTION}

Rock weathering is the main source of silicon to the aquatic systems. The silicate input via rivers constitutes a representative contribution to oceanic biogeochemical cycle of this nutrient element. Silicon is present in the marine environment under three different forms: dissolved silicate (DSi), particulate biogenic silica (BSi) and particulate lithogenic silica (LSi). Continental margins have great importance for the Si cycle due two main reasons: $i$ ) considering that these areas are the most productive, they are sites of BSi sinking; and ii) these areas act as a filter to withholding the input of Si to the open ocean as, for example, discussed by Ragueneau et al. (2005).

The major part of the studies of silicon is centered in the dissolved reactive silicon (DSi) presenting varied conclusion on the behavior in estuaries as showed in the classical work of DeMaster (1981) and Blancherd (1988). The conservative profile associated to salinity is always mentioned considering DSi, and the LSi is easily associated to terrestrial inputs and sediment resuspension, however, about $\mathrm{BSi}$, the noticed data is rare in estuarine and coastal waters. The association of these forms could play relevant information about the metabolism of the hydrological systems and show the anthropogenic influence concerning to the human soil occupation, eroded areas, sewage disposal and so on. Studies about silicon form on the continental shelf. This could contribute to elucidate some biogeochemical processes.

The State of Pernambuco, located in Brazilian tropical northeastern area is $187 \mathrm{~km}$ long and lodge $44 \%$ of the population, resulting in places with a population density higher than 900 habitants $\mathrm{km}^{-2}$ (Araújo et al., 2007). The Recife city, considered the main urban center of northeastern Brazilian region (Santiago et al., 2010) is an important local for studies of environmental impact.

The coastal region of Recife has a common estuary to Capibaribe and Beberibe Rivers, where a port terminal is located. It is also close to the estuaries of the Timbo river and Jaboatão River, that receiving a considerable input of domestic and industrial effluents (Souza, 2011). The main river of the region is the Capibaribe River, whose basin covers an area of $7454.88 \mathrm{~km}^{2}$ and has an average flow of $20 \mathrm{~m}^{3} \mathrm{~s}^{-1}$ (Anjos et al., 2012).

The first records of erosion in the region date back to the early twentieth century, due to the construction and expansion of the port that altered the conditions of coastal currents (SHR, 2010; Borges et al., 2012). This problem was aggravated by the absence of major rivers and the narrow continental shelf (Araújo et al., 2007; Souza, 2011). In this area, there is a strong human intervention to control erosion, which includes actions such as the construction of rock-fill breakwaters and the nourishment of beaches (Araújo et al., 2007).

The dominate climate is classified as warm, with average annual temperature of $25.6{ }^{\circ} \mathrm{C}$, and humid (average humidity of $90 \%$ ) (Borges et al., 2012). The rainfall pattern is divided into two distinct periods: rainy season, from May to August, with monthly rainfall ranging from $100 \mathrm{~mm}$ to $400 \mathrm{~mm}$, and dry season, from September to April, with monthly precipitation lower than $100 \mathrm{~mm}$ (Rollnic et al., 2011).

The tides are semidiurnal, with an average height of $2.6 \mathrm{~m}$ in spring tides and $1.6 \mathrm{~m}$ in neap tides (Santiago et al., 2010). During the rainy season, the SE winds are stronger and more constant, resulting in a transport to northern throughout the water column. In the dry season, the winds are more variable, with the majority being of NE-E, resulting in surface transport to the southern and not determined in the bottom (Rollnic et al., 2011).

This study aims to evaluate the environmental impact of a heavily urbanized river observing the behavior of different silicate forms, undertaking biogeochemical profiles in the region adjacent to the river mouth with special regard on terrestrial transport signalized by LSi and by biogenic silica that have significative relation with the phytoplankton, mainly associated to diatoms.

\section{MATERIAL AND METHODS}

\section{STUDY AREA}

This study was performed in the coastal region adjacent to the mouth of Capibaribe River, where the port channel is located. The Capibaribe River has a hydrological system that crosses the metropolitan area of Recife, after passing through several cities of Pernambuco state. A total of 9 stations was evaluated to compose a silicon distribution scenario in this area (Fig. 1).

The samples were collected during July, 2013 (rainy season in the context of the Project "Study of the balance of the carbon cycle in the coastal region and its potential transport to the ocean with emphasis at Pernambuco state coast. (CARECOS- FAPESP n.2011/50582-0). The sampling were obtained with support of $\mathrm{B} / \mathrm{Pq}$ Alpha Delphini, a research vessel of Oceanographic Institute of the University of São Paulo (IO-USP). 


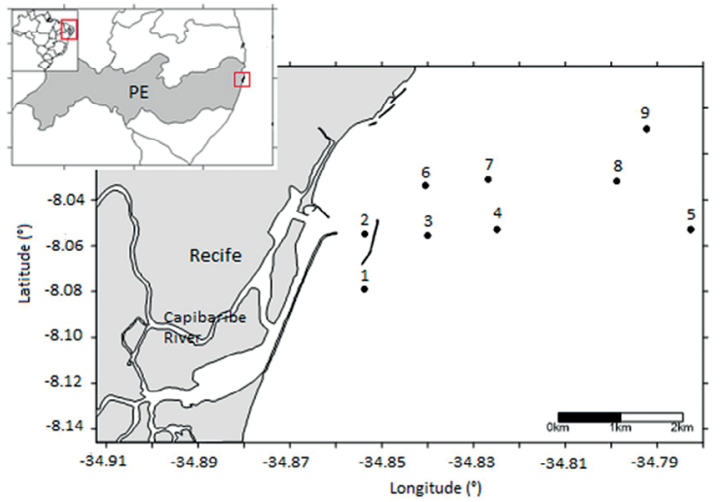

Figure 1. Location of the sampling stations in the Recife coast, Pernambuco state, Brazil, (July, 2013).

\section{Methodology}

Water temperature and salinity profiles were measured in situ using a CTD Seabird ${ }^{\mathbb{R}}$, with precision of \pm 0.01 ${ }^{\circ} \mathrm{C}$ and \pm 0.01 , respectively. Water $\mathrm{pH}$ was measured with an Orion ${ }^{\circledR} 290 \mathrm{~A}$ pHmeter, accuracy of \pm 0.001 , following the recommendations of Aminot and Chaussepied (1983). Turbidity was analysed with 2100P Turbidimeter, Hach ${ }^{\circledR}$.

Water samples were filtered in Whatman $\mathrm{GF} / \mathrm{F}^{\circledR}$ membranes, porosity of $0.45 \mu \mathrm{m}$. and the filters were used to determine the content of suspended particulate matter (SPM), via the gravimetric method (precision of $\pm 0.01 \mathrm{mg}$ $\left.\mathrm{L}^{-1}\right)$ and chlorophyll- $a$, determined by colorimetric method (precision of $\pm 0.01 \mathrm{mg} \mathrm{m}^{-3}$ ), both described in Strickland and Parsons (1968).

Water samples for the analyses of dissolved silicate were filtered in polycarbonate membrane (porosity of $0.45 \mu \mathrm{m}$ - HTTP04700 isopore Millipore ${ }^{\circledR}$ ) and preserved in polyethylene bottles at $-20^{\circ} \mathrm{C}$ until chemical analysis. Reactive dissolved silicate (DSi) was analyzed following the colorimetric method described in Grasshoff et al. (1983), precision of $\pm 0.01 \mu \mathrm{mol} \mathrm{L}{ }^{-1}$. Biogenic silica (BSi) was obtained by the digestion method as presented by Ragueneau and Tréguer (1994). The material, previously retained on a polycarbonate filter, was dried for 12 hours at $60{ }^{\circ} \mathrm{C}$ and treated with $4.0 \mathrm{ml}$ of $\mathrm{NaOH} 0.2 \mathrm{~mol} \mathrm{~L}^{-1}$ at $100{ }^{\circ} \mathrm{C}$ for $40 \mathrm{~min}$ in a plastic tube. After cooling, $1.0 \mathrm{ml}$ de $\mathrm{HCl} 1 \mathrm{~mol} \mathrm{~L}^{-1}$ was added to solution. The sample was centrifuged for $10 \mathrm{~min}$ at $1500 \mathrm{rpm}$. After that, $1.0 \mathrm{ml}$ of supernatant was removed and diluted to $50 \mathrm{ml}$ with distilled water. The analysis of dissolved silicate followed the described in Grasshoff et al. (1983), yielding the apparent biogenic silica $\left(\mathrm{BSi}_{\mathrm{a}}\right.$ ). To eliminate the interference of lithogenic silica, the following correction was made:

$$
\mathrm{BSi}=\mathrm{BSi} \mathrm{a}_{\mathrm{a}}-\mathrm{k} \cdot \mathrm{LSi} \mathrm{a}_{\mathrm{a}}
$$

where $\mathrm{k}$ is a constant depended on the mineralogy of the considered area. In this study, a mean of 0.15 was adopted for $\mathrm{k}$. LSi $\mathrm{a}_{\mathrm{a}}$ corresponds to the apparent lithogenic silica, whose determination is next described. The accuracy of the method is $\pm 0.1 \mathrm{mmol} \mathrm{L}^{-1}$.

After BSi digestion, the supernatant was removed and discarded; following $12 \mathrm{ml}$ of distilled water were added. The tubes were shaken and centrifuged for $10 \mathrm{~min}$ at 1500 rpm and then $12 \mathrm{ml}$ supernatant extracted and discarded. If the concentration of BSi was greater than $5.0 \mathrm{mmol} \mathrm{L}^{-1}$, the procedure was repeated. The tube containing the filter was then covered with a sheet of aluminum foil and dried at $80{ }^{\circ} \mathrm{C}$ for $12 \mathrm{~h}$. The sample was treated with $0.2 \mathrm{ml}$ of $\mathrm{HF}$ $2.9 \mathrm{~mol} \mathrm{~L}^{-1} \mathrm{f}$, resting for $48 \mathrm{~h}$. Then, add $10 \mathrm{ml}$ of distilled water and stir. The remaining solution was diluted until the HF concentration reaches values less than $0.002 \mathrm{mmol} \mathrm{L}^{-1}$. The analysis of dissolved silicate follows the described in Grasshoff et al. (1983), yielding the apparent silicon lithogenic $\left(\mathrm{LSi}_{\mathrm{a}}\right)$. The LSi concentration was calculated by the expression: $\mathrm{LSi}=\mathrm{TSi}-\mathrm{BSi}$, where $\mathrm{TSi}$ is the total concentration of silicon present in the filter $\left(\mathrm{BSi}_{\mathrm{a}}+\mathrm{LSi}_{\mathrm{a}}\right)$. The accuracy of the method is $\pm 0.5 \mathrm{mmol} \mathrm{L}^{-1}$.

\section{DATA TREATMENT}

Spearman's nonparametric correlation $(r s)$ was performed using the Excel $2013^{\circledR}$ software. Principal component (PCA) and group (cluster) analyses were undertaken using Primer 6 (Past x) software. The spatial distribution of the parameters studied was set out using figures composed in Excel.The data were treated with a significance level $\alpha=0.05$ to identify whether there were spatial differences between the Pearson and PCA graphics.

\section{RESULTS}

The range of variables (temperature, salinity, turbidity, DSi, BSi, LSi, SPM and Chlorophyll-a) obtained in this study are showed in the Fig 1 . Concerning to water temperature, a little variation, from $25.46{ }^{\circ} \mathrm{C}$ to $26.08^{\circ} \mathrm{C}$, was observed. In most of stations, the temperature was constant throughout the water column. The exception occurred at station 2, located closer to the mouth of the Capibaribe River and in the port area, which showed a slightly lower surface temperature. The stations 3 and 6 presented a weak thermal stratification with minor temperatures in the bottom waters (Fig. 2a).

Salinity and $\mathrm{pH}$ ranged from 33.93 to 36.50 and from 8.09 to 8.20 , respectively. The lowest values for both were found at stations 2 and 6 , due to the increasing of the 


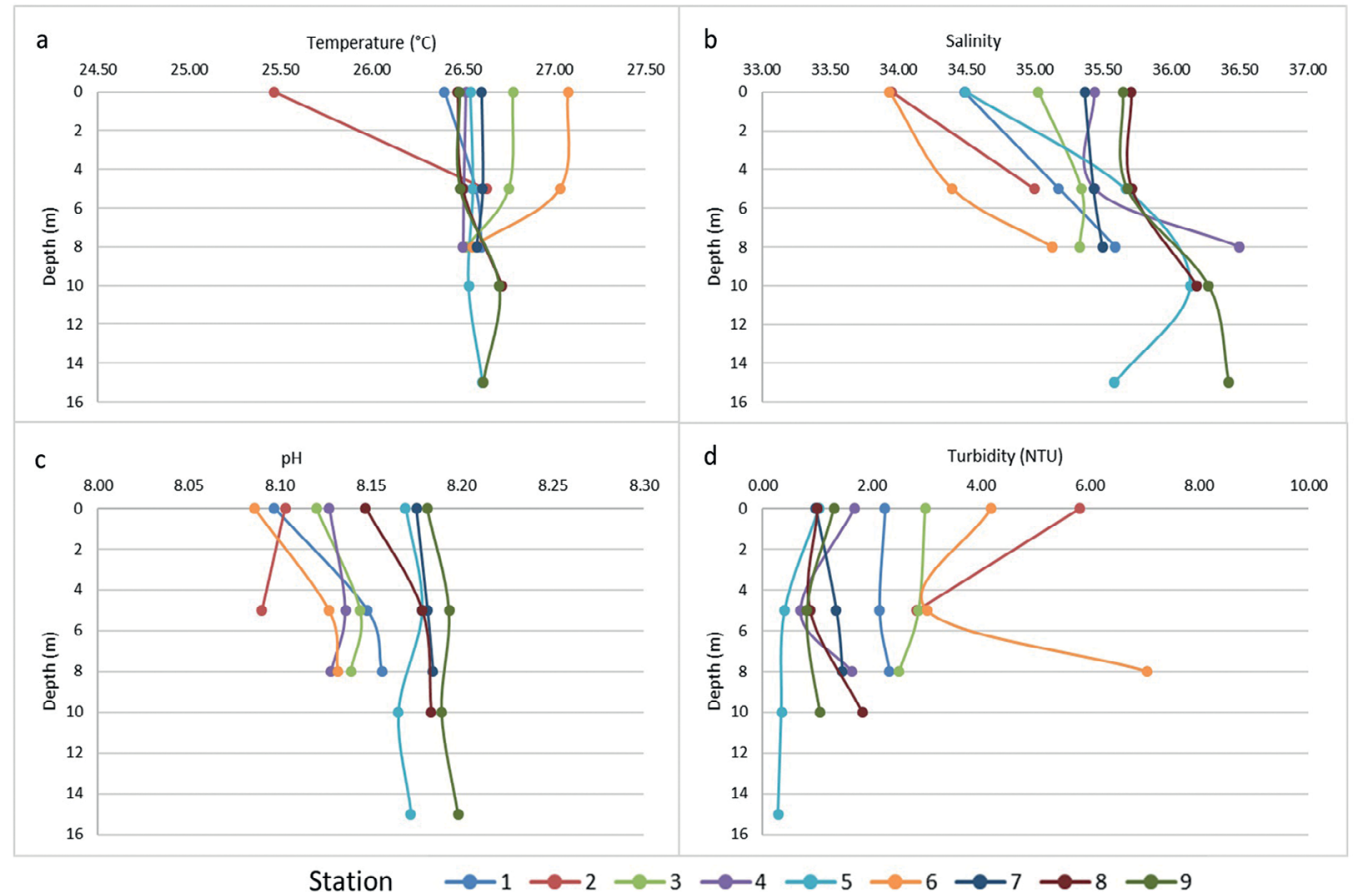

Figure 2. Vertical profile per station of temperature $\left({ }^{\circ} \mathrm{C}\right)$, salinity, pH and turbidity (NTU) in Recife (PE), Brazil, in July 2013.

influence of river water, once they are located near the mouth of the Capibaribe River and in northeastern sense. In general, salinity was lower at the surface and increased toward the bottom, however showing lower values in stations 2 and 6 (Fig. 2b). The stations 7, 8 and 9, relatively distant from the river influence showed the highest values of $\mathrm{pH}$ (Fig. 2c).

The turbidity had a minimum value of 0.29 NTU and a maximum of 7.04 NTU. Stations 2 and 6, where terrestrial input has a greater influence, exhibited the highest values, while the lowest were found in the stations farthest from the coast (5, 8 and 9 stations), with the lowest values observed in station 5, the more distant from the coast (Fig. 2d).

Dissolved silicate (DSi) concentrations ranged from $2.63 \mu \mathrm{mol} \mathrm{L}^{-1}$ to $14.40 \mu \mathrm{mol} \mathrm{L}^{-1}$. The highest values were found on the surface of the stations 2 and 6 , where the influence of river input was higher (Fig. $3 a)$, toward the bottom, concentration decreases. In the other stations further away from the mouth of the Capibaribe River, silicate concentrations were lower and decreased slightly with depth, excepted in station 8 , that demonstrated a slight increase in the bottom concentration (Fig. 3b).
In general, BSi concentrations were relatively low, ranging from values below the detection limit of the method

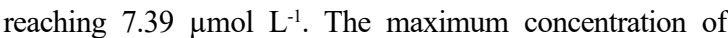
BSi was observed on the surface of station 2 (Fig. 3c), influenced by river input, decreasing toward the bottom. In the other stations, the values were smaller than $2 \mu \mathrm{mol} \mathrm{L}^{-1}$, being constant throughout the water column, with different behavior in station 4 which showed lower concentrations of BSi on the surface, increasing toward the bottom (Fig. 3d). LSi concentrations showed values lower than the detection limit of the method, reaching $25.76 \mu \mathrm{mol} \mathrm{L}^{-1}$. The highest values were found in the bottom layer of the stations 2 and 6 (greater fluvial influence), decreasing toward the surface, while the lowest concentrations observed in stations 5, 8 and 9 , which are further away from the coast, with little vertical variation. LSi in station 4 had an inverse behavior to that observed for the $\mathrm{BSi}$, i.e., the concentration was higher on the surface, decreasing toward the bottom (Figs. 3e and 3f).

Values of SPM ranged from $16.50 \mathrm{mg} \mathrm{L}^{-1}$ to $51.69 \mathrm{mg}$ $\mathrm{L}^{-1}$. In general, the concentration decreased with the distance from the coast, and consequently distant from the river influence (Fig. 4a).The highest values were obtained in station $4,(5 \mathrm{~m})$ and in the bottom of station 1 , while the lowest values were observed in station 8 (Fig. 4b). 

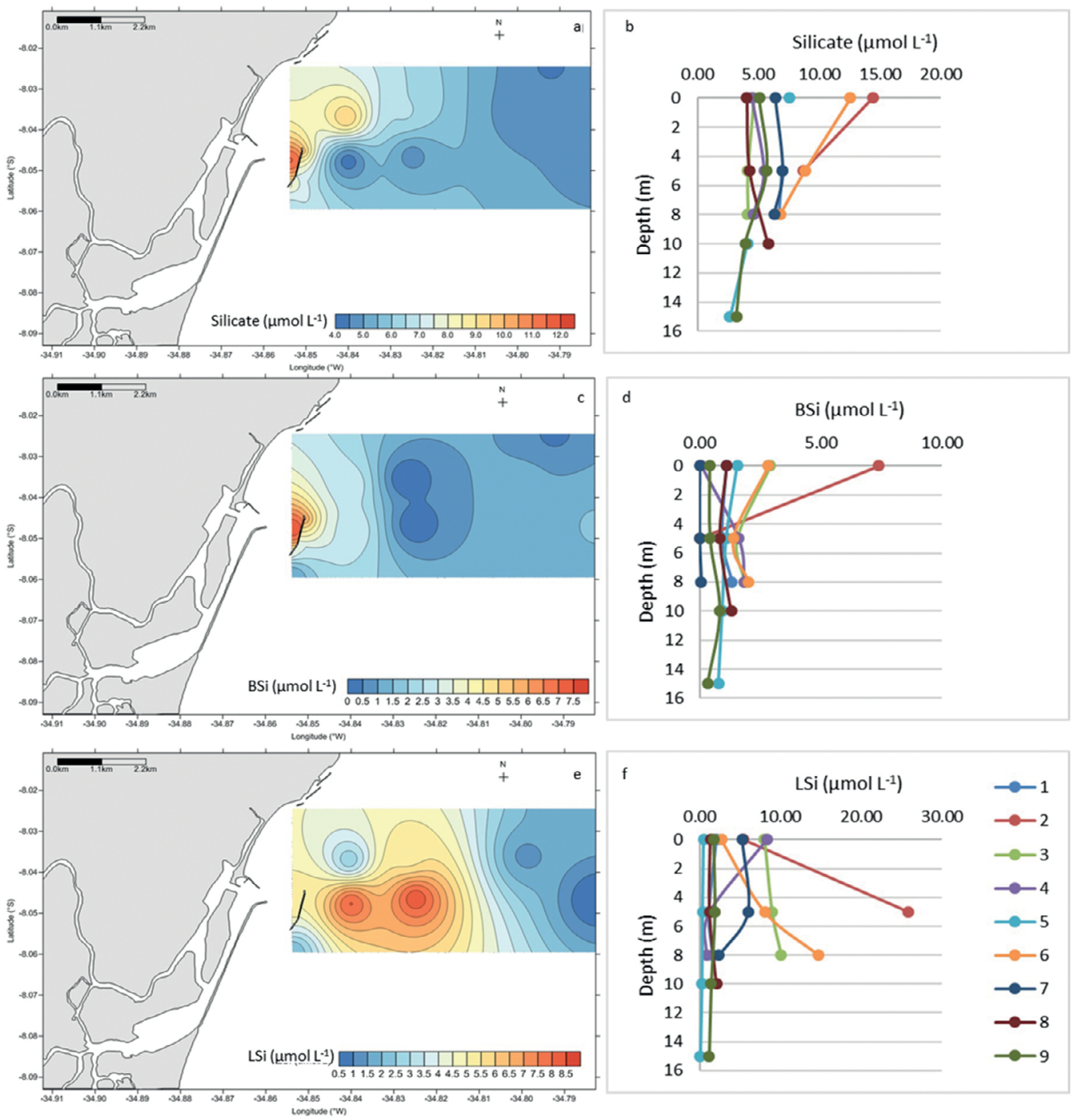

Figure 3. Surface and vertical distribution of silicate $\left(\mu \mathrm{mol} \mathrm{L}^{-1}\right)(\mathrm{a}, \mathrm{b}), \mathrm{BSi}\left(\mu \mathrm{mol} \mathrm{L} \mathrm{L}^{-1}\right)(\mathrm{c}, \mathrm{d})$ and LSi $\left(\mu \mathrm{mol} \mathrm{L} \mathrm{L}^{-1}\right)(\mathrm{e}, \mathrm{f})$ in the coast of Recife (PE), in July 2013.

The concentrations of chlorophyll- $a$ ranged from 0.10 $\mathrm{mg} \mathrm{m}^{-3}$ to $4.87 \mathrm{mg} \mathrm{m}^{-3}$ (Tab. 1). The surface distribution of chlorophyll- $a$ (Fig. 4c) was similar to that of dissolved silicate and BSi, namely, it was higher at the mouth of Capibaribe River, decreasing in the eastern stations. The highest values of chlorophyll- $a$ were found on the surface of stations 2 and 6 (Figs. 4c, d), where the concentration of dissolved nutrients is enhanced due to the influence of riverine input, as demonstrate by silicate concentrations.

\section{DISCUSSION}

In general, water temperature showed relatively high values and near the Capibaribe river mouth and a decreasing was associated to the lowest values of salinity evidenced the water input of river to ocean. This influence decrease to seaward and the station 3 and 6, relatively near the coast and in direction to the Northeast showed a thermal stratification in function of the trace of the river plume. 

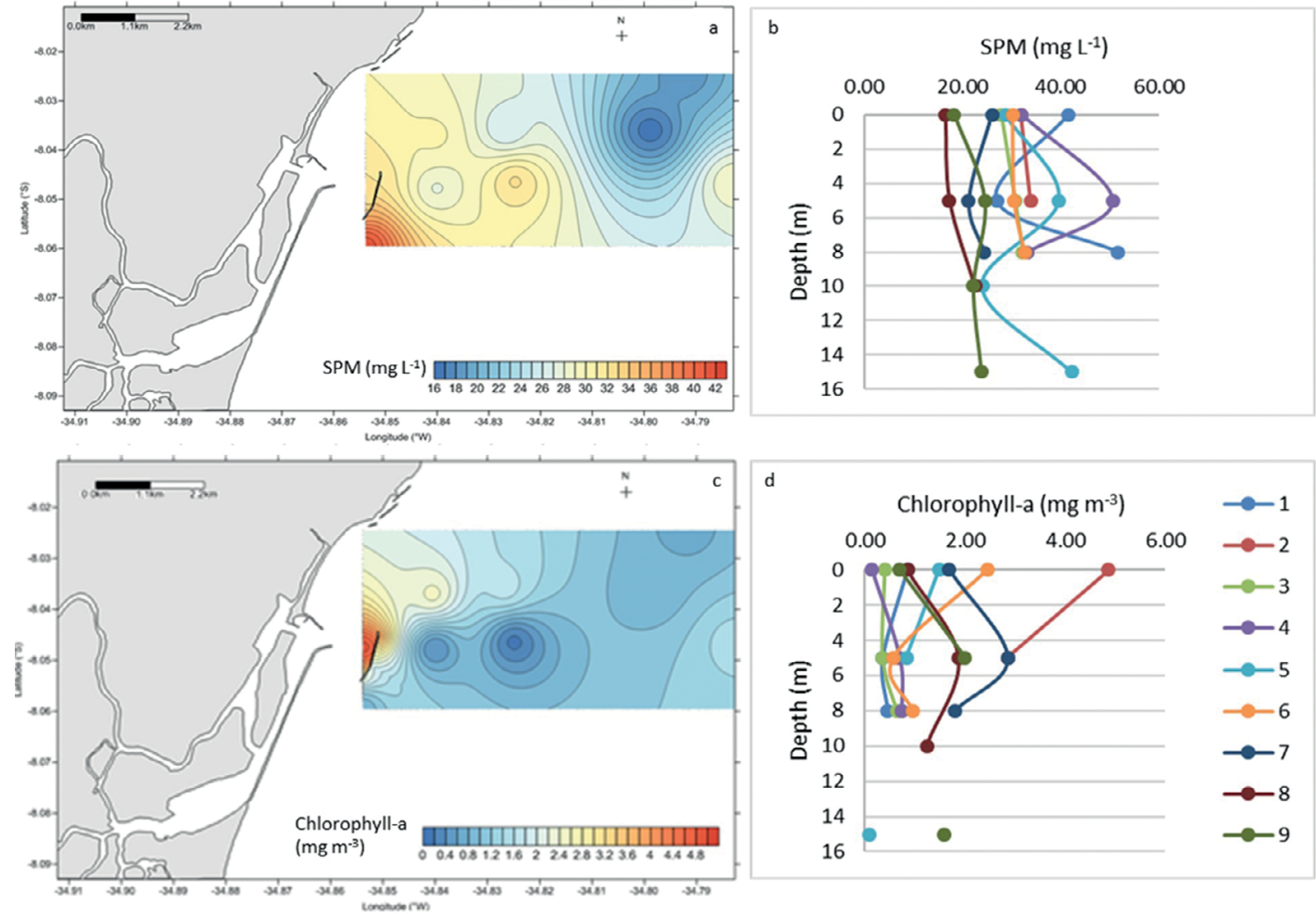

Figure 4. Surface and vertical distribution of SPM $\left(\mathrm{mg} \mathrm{L}^{-1}\right)(\mathrm{a}, \mathrm{b})$ and chlorophyll- $a\left(\mathrm{mg} \mathrm{m}^{-3}\right)(\mathrm{c}, \mathrm{d})$ in the coast of Recife (PE), in July 2013.

Table 1. Descriptive statistics (maximum, minimum, mean, median and standard deviation - SD) of the water parameters: temperature $\left({ }^{\circ} \mathrm{C}\right)$, salinity, $\mathrm{pH}$, turbidity $(\mathrm{NTU})$, silicate $\left(\mu \mathrm{mol} \mathrm{L} \mathrm{L}^{-1}\right)$, BSi $\left(\mu \mathrm{mol} \mathrm{L} \mathrm{L}^{-1}\right), \mathrm{LSi}\left(\mu \mathrm{mol} \mathrm{L} \mathrm{L}^{-1}\right), \mathrm{SPM}\left(\mathrm{mg} \mathrm{L}^{-1}\right)$ and chlorophyll- $a\left(\mathrm{mg} \mathrm{m}^{-3}\right)$ analyzed in Recife (PE), July - 2013, (n=28).

\begin{tabular}{lccccccccc}
\hline & $T$ & $S$ & $p H$ & $\begin{array}{c}\text { Turb. } \\
(N T U)\end{array}$ & $\begin{array}{c}\text { DSi } \\
\left(\mu \mathrm{mol} \mathrm{L} \mathrm{L}^{-1}\right)\end{array}$ & $\begin{array}{c}\text { BSi } \\
\left(\mu \mathrm{mol} \mathrm{L} \mathrm{L}^{-1}\right)\end{array}$ & $\begin{array}{c}\text { LSi } \\
\left(\mu \mathrm{mol} \mathrm{L} \mathrm{L}^{-1}\right)\end{array}$ & $\begin{array}{c}\text { SPM } \\
\left(\mathrm{mg} \mathrm{L}^{-1}\right)\end{array}$ & $\begin{array}{c}\text { Chlo-a } \\
\left(\mathrm{mg} \mathrm{m} \mathrm{m}^{-3}\right)\end{array}$ \\
\hline Max. & 27.08 & 36.50 & 8.20 & 7.04 & 14.40 & 7.39 & 25.76 & 51.69 & 4.87 \\
Min. & 25.46 & 33.93 & 8.09 & 0.29 & 2.63 & $<\mathrm{DL}$ & $<\mathrm{DL}$ & 16.50 & 0.10 \\
Mean & 26.57 & 35.38 & 8.15 & 2.02 & 6.07 & 1.29 & 4.19 & 29.95 & 1.28 \\
SD & \pm 0.26 & \pm 0.67 & \pm 0.03 & \pm 1.60 & \pm 2.71 & \pm 1.43 & \pm 5.72 & \pm 8.94 & \pm 1.08 \\
Median & 26.56 & 35.44 & 8.15 & 1.63 & 5.56 & 1.08 & 1.83 & 29.50 & 0.86 \\
\hline
\end{tabular}

The salinity as a conservative property showed the mixing of the waters from the river to the ocean and a northeastward displacement. According to this, some dissolved properties could present a similar behavior under river and marine current influence and also, associated to the mixing process (Liss, 1976). The non-conservative properties, on the other hand, suffer influence of biogeochemical processes, contributing to a differenced behavior. In the other side, the anthropogenic actions contribute in both processes. The turbidity presented significant negative relation $(r=-0.59)$ with the salinity, showing the riverine source of material from river and reflecting the inputs from erosion and sewage disposal along the river.
In seawater, the $\mathrm{pH}$ normally exhibit slightly variation due to the buffer property of the seawater associated to carbonate system and others weak acid interactions as the orthosilicic acid, however under influence of the fresh water, the buffer property decrease and the $\mathrm{pH}$ changing contributes as tracer of the river plume and, in this study, it was either associated to the SPM transport.

The SPM presented significant negative correlation with $\mathrm{pH}(\mathrm{r}=-0.40)$, and showed no correlation with turbidity and with particulate forms of silicon indicating the influence of multiple source inputs within an estuary and coastal area as observed by some authors (Boyle et al., 1974; Liss, 1976; Bell, 1994). This parameter had its 
highest values in southwestern stations, decreasing toward the Eastern. The SPM values were superior to those found by Medeiros and Kjerfve (1993) in Itamaracá (from $5 \mathrm{mg}$ $\mathrm{L}^{-1}$ to $30 \mathrm{mg} \mathrm{L}^{-1}$ ) and by Bastos et al. (2011) in Ipojuca (from $2.2 \mathrm{mg} \mathrm{L}^{-1}$ to $30 \mathrm{mg} \mathrm{L}^{-1}$ ), both located in the coastal area of State of Pernambuco, receiving influence of rainy period.

Dissolved silicate (DSi) presented significant negative correlation with salinity and $\mathrm{pH}(\mathrm{r}=-0.81)$. It also showed a significant positive correlation with turbidity $(\mathrm{r}=0.63)$, indicating fluvial source, with higher values near the mouth of the river, decreasing towards the East. The values obtained in this study were similar to those observed by Koening and Macêdo (1999), with a variation of $1.42 \mu \mathrm{mol} \mathrm{L}^{-1}$ to $10.71 \mu \mathrm{mol} \mathrm{L}^{-1}$ in Itamaracá (State of Pernambuco), and those observed by of Costa (2007) that showed a variation from $2.13 \mu \mathrm{mol} \mathrm{L}-1$ to $11.47 \mu \mathrm{mol} \mathrm{L}^{-1}$ in Porto Seguro (State of Bahia). They also noted a decrease in nutrient concentrations, increasing with the distance from the coast. A significant positive correlation $(\mathrm{r}=0.72)$ was also observed with chlorophyll (discussion below) showing its availability to siliceous organisms.

The classical role of salinity and temperature as tracer of fresh water contribution in estuarine and coastal waters is confirmed and enhanced by $\mathrm{pH}, \mathrm{SPM}$ and DSi data as observed by Hunt and Foster (1977); Helder et al. (1983); Bell (1994) and others.

The BSi showed significant negative correlations with temperature $(r=-0.55)$, salinity $(r=-0.52)$ and $\mathrm{pH}(\mathrm{r}=$ $-0.50)$, and positive correlations with turbidity $(\mathrm{r}=0.64)$ and DSi ( $\mathrm{r}=0.62)$. Its distribution was quite similar to that of silicate, indicating that presence of marine diatoms and siliceous organisms are most evident in the stations closer to the shore which presented lowest values of salinity in relation to the distant stations. Certainly, the availability of essential nutrients is an important factor to favoring the marine diatoms development promoting the incorporation of $\mathrm{BSi}$, on the other hand, the turbidity increasing and $\mathrm{BSi}$ correlation showed the possibility of the contribution of freshwater phytoplankton species. The case of the BSi in the stations next to the mouth of the river could be associated not only to diatoms, but also to microphytoliths.

The LSi had no correlation with salinity or with other forms of silicon, but had negative correlation with $\mathrm{pH}(\mathrm{r}=$ -042) and positive with turbidity $(\mathrm{r}=0.39)$. Its distribution was different from that of the other parameters with the highest concentrations on the surface of stations 3 and 4 , and near the bottom. This suggests that the major LSi source in this area is linked to sediment re-suspension and/ or to silicate adsorption in the SPM, yielding LSi. So, LSi source is mainly associated to particle transport and remobilization and therefore not only so associated to fresh water dispersion.

The contribution to the $\mathrm{pH}$ mechanism present different participation of the DSi in brackish waters and salt waters, but a significant correlation was observed between DSi and $\mathrm{pH}(\mathrm{r}=0.58)$.

There are few studies that present data of BSi and LSi in continental margins. Table 2 summarizes the results of other studies, allowing comparison with those obtained in the present study. Rare as the results found of BSi and LSi the Brazilian coast reiforncing this contribution.

In relation to the values cited in the Table 2, the $\mathrm{BSi}$ maximum value in this study are bellow from that observed at California Bay, by Firme et al. (2003), reported as $42 \mu \mathrm{mol} \mathrm{L} \mathrm{L}^{-1}$ being associated to makeable presence of diatoms and to a fertilization process. In the case of the LSi, the maximum value $\left(25.8 \mu \mathrm{mol} \mathrm{L}^{-1}\right)$ was presented by this study, with value above the maximum observed by Ragueneau et al. (2005) in the North Sea $\left(19.0 \mu \mathrm{mol} \mathrm{L}^{-1}\right)$, which was also associated to the terrestrial inputs from the ice sliping. The corroboration to the erosion by anthropogenic influence is reasonable to explain the high values of these parameters observed in the current study.

In relation to the concentration of determined $\mathrm{Si}$ forms (Fig. 5) in the studied system, it was observed the representative participation of DSi in the station 2 , located in the mouth of Capibaribe river and in the station $6(0 \mathrm{~m})$, located westward in river plume. LSi showed a presence more evident as the DSi increased the station 3 signal. The biogenic form, BSi, presented no signal in station 7 , located relatively distant from the coast, and the lowest values were observed really far from the coast, exception in the station 1 , due to the marine current that bring oligotrophic waters from southern to near the coast. Effectively, the BSi value in the station 2 was the highest observed, possibly reflecting terrestrial contribution, and autoctone production resulting from the nutrients availability to a population that survive in the estuarine mixing condition.

Considering the biological aspects, the observed concentrations of chlorophyll- $a$ (from $0.10 \mathrm{mg} \mathrm{m}^{-3}$ to $4.87 \mathrm{mg}$ $\mathrm{m}^{-3}$ ) had lower values than those obtained by Bastos et al. (2011) (from $1.11 \mathrm{mg} \mathrm{m}^{-3}$ to $18.72 \mathrm{mg} \mathrm{m}^{-3}$ ) and by Fonseca et al. (2002) (from $0.16 \mathrm{mg} \mathrm{m}^{-3}$ to $9.36 \mathrm{mg} \mathrm{m}^{-3}$ ) in Ipojuca (coastal area of State of Pernambuco). The latter were relative lower than others in coastal areas of Pernambuco 
Table 2. Values of BSi e LSi found by this and other studies in continental margins.

\begin{tabular}{|c|c|c|c|}
\hline Area & $\begin{array}{c}\mathrm{BSi} \\
\left.(\mu \mathrm{mol} \mathrm{L})^{-1}\right)\end{array}$ & $\begin{array}{c}\mathrm{LSi} \\
(\mu \mathrm{mol} \mathrm{L}-1)\end{array}$ & Reference \\
\hline Santa Barbara (USA) & $0-3.5$ & $0-2.0$ & Shipe \& Brzezinski (2001) \\
\hline California Coast (USA) & $0.1-42.0$ & - & Firme et al. (2003) \\
\hline $\begin{array}{l}\text { South America West Coast } \\
\left(0^{\circ} \mathrm{N}-14^{\circ} \mathrm{N}\right)\end{array}$ & $<0.1-4.2$ & - & Shipe et al. (2006) \\
\hline China East Sea & $0.2-2.8$ & - & Liu et al. (2005) \\
\hline Bay of Brest (France) & $0.4-2.1$ & $1.2-2.8$ & Ragueneau et al. (2005) \\
\hline Bay of Seine (France) & $1.1-5.8$ & $0.7-3.8$ & Ragueneau et al. (2005) \\
\hline North Sea & $0.1-2.3$ & $2.5-19.0$ & Ragueneau et al. (2005) \\
\hline Concéption (Chile) & $0.4-23.0$ & $0.1-8.0$ & Sánchez et al. (2008) \\
\hline Recife coast (Brazil) & $0-7.4$ & $0-25.8$ & This study \\
\hline
\end{tabular}

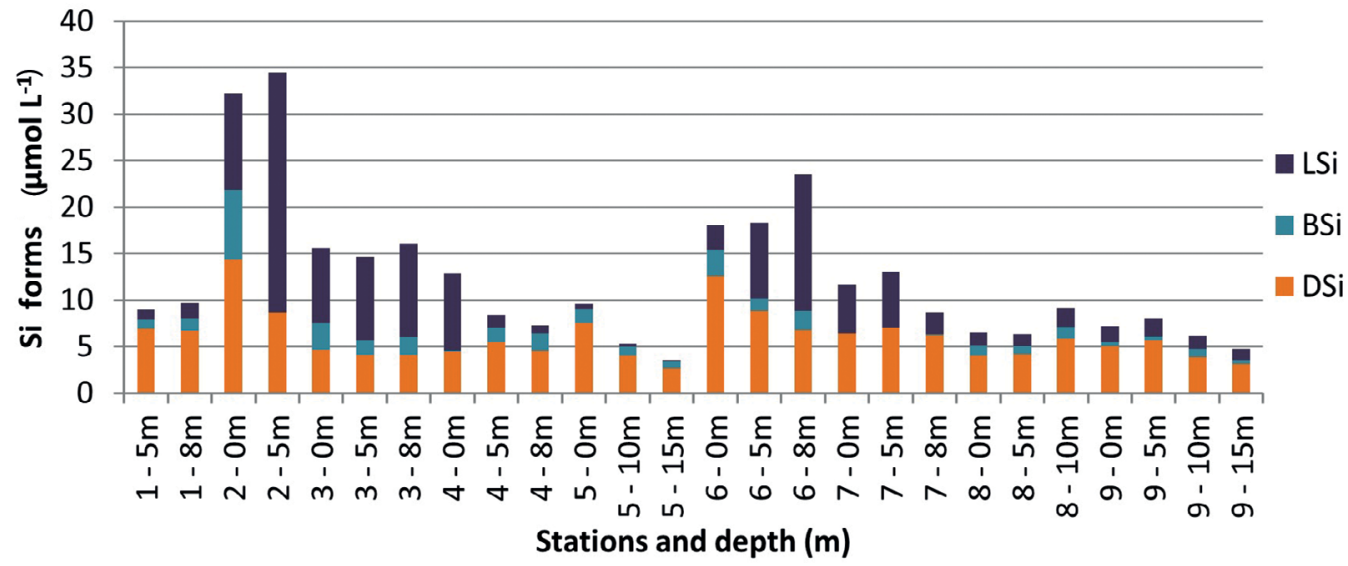

Figure 5. Concentration of DSi (blue); BSi (red) and LSi (gray) in the coast of Recife (PE), in July 2013.

indicating the general oligothrophic conditions with punctual fertilization supporting a wholesome primary production in coastal area, but needing monitoring action to avoid eutrophication process besides the estuarine environment. Chlorophyll- $a$ showed a significant negative correlation with temperature $(\mathrm{r}=-0.50)$ and salinity $(\mathrm{r}=-0.38)$, and positive correlation with DSi $(r=0.72)$ and BSi $(r=0.44)$ confirming the link with siliceous organisms.

It was observed also relatively high values of chlorophyll- $a$ in stations 7, 8 and 9 at $5 \mathrm{~m}$ depth, not exactly associated to BSi, but possibly it could be associated to others kind of primary producers as coccolihophores that have a calcareous skeleton and they are considered important actors of the primary production (Honjo, 1976; Hay, 2004; Rost and Riebesell, 2004) in the oceans, contributing to carbon cycle. It is also important to the mentioned participation of the calcareous algae in primary production, overall on northern of this area, in front of Itamaraca island and in other Brazilian coastal sectors as showed by Silva et al. (1987); Torres et al. (2004); Figueiredo et al. (2008).

To better understand the relationship between BSi and primary production, the ratio $\mathrm{BSi} / \mathrm{Chlorophyll}-a(\mathrm{BSi} /$ Chlo- $a$ ) was calculated (Fig. 6). Where the values of BSi and chlorophyll- $a$ were proportional (i.e., low BSi low chlorophyll- $a$ or high BSi high chlorophyll- $a$ ) the ratio BSi/ Chlo- $a$ approached 1, probably indicating that diatoms and other siliceous phytoplankton have a major role in primary production. The ratio was near 1 at the surface of stations $1,2,5,6$ and 8 , in station 5 at $5 \mathrm{~m}$ and in station 8 at $10 \mathrm{~m}$. Based on these points a tendency line was plotted (Fig. 6) showing that the values of BSi and chlorophyll- $a$ have a significant positive linear correlation with $\mathrm{r}=0.99$.

At the surface of stations 4,9 and 7, at $5 \mathrm{~m}$ depth of stations 2, 7, 9 and 8 and at the bottom of stations 7 and 9, the ratios $\mathrm{BSi} / \mathrm{Chlo}-\mathrm{a}$ were below 1 , i.e. low $\mathrm{BSi}$ and relatively high chlorophyll- $a$. This may indicate that non-siliceous 


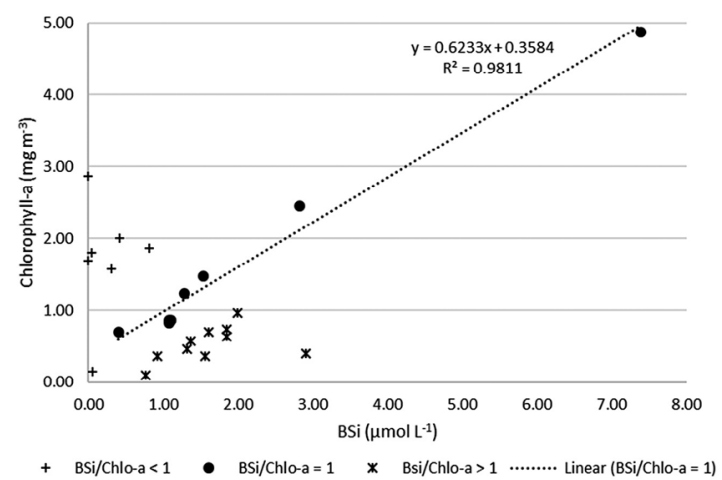

Figure 6. Chlorophyll- $a$ versus $\mathrm{BSi}$, and the ratio BSi/Chlo- $a$. BSi/ Chlo- $a<1$ is represented by a cross, BSi/Chlo- $a=1$ in circles and BSi/ Chlo- $a>1$ in stars. The tendency line refers to the points where BSi/ Chlo- $a=1$ only.

phytoplankton is responsible for primary production. In Figure 5 these points are plotted above the tendency line.

Where the ratio $\mathrm{BSi} /$ Chlo- $a$ was above $1, \mathrm{BSi}$ was high and chlorophyll- $a$ had lower values, suggesting the presence of frustules of diatoms (and other siliceous phytoplankton) and perhaps microphytoliths. These particles may be sinking or being ressuspended from the sediment since the points that had this behavior are located mainly at the bottom of stations $1,3,4,5$, and 6 . These points are plotted in Figure 5 bellow the tendency line.

The adjacent coastal area of Recife in its nothwestern portion has a more pronounced fluvial influence, due to the circulation action on the river plume spreading (Schettini et al., 2016) and the role of the breakwater indicated by lower salinity and higher dissolved silicate concentrations, leading to a higher primary production indicated by higher concentrations of chlorophyll- $a$ and BSi. The more eastern section present stations with more significant characteristics of oligotrophic waters, evidenced by low concentrations of all forms of silicon.

The influence of the estuary water in this coastal area was observed by some authors between them Bryner et al. (2003); Guenther et al. (2015); Maciel et al. (2015); Travassos et al. (2016); and Martins et al. (2016), whose studied some pollution markers introduced by the urbanized and industrialized Capibaribe rivers. This study showed that the behavior and association of the components of silicon cycle can corroborate these river inputs and to evidence coastal biogeochemical and physical processes on this coastal zone with emphasis to testimony of primary production actors contribution.

Considering nutrients data support as nitrate, nitrite, $\mathrm{N}$-ammonium and silicate from databank of the Carecos
Project, it was possible to verify the proximity between $\mathrm{N}$ and $\mathrm{P}$ nutrients to the forms of silicate studied (DSi and BSi) and major relation of LSi to SPM, MO and turbidity (Fig. 7).

In future perspectives, this study could encourage the continuity of investigation to link the preterit process of deposition and resuspension of silicon forms in sediments under influence of the time, climate changes and the displacement of the ITCZ, as indicated by Romero et al. (1999) on the continental shelf sectors, with possibility of distinction of the natural and anthropogenic influence.

\section{CONCLUSION}

The coastal region of Recife (PE), although located in the tropical zone, characterized by waters poor in nutrient, is under the influence of fluvial inputs from the Capibaribe and Beberibe Rivers that crossing the city. Thus, distributions of certain parameters, including silicate and BSi have shown that riverine influence, coming from the west, reaching the barrier and propagating toward the northeast traced by physical signal as salinity and turbidity but also by members of silicon cycle that signalize physical and biogeochemical processes.

As there was a highlighted nutrient input in this region, primary production was encouraged, recorded by chlorophyll- $a$ values accompanied by BSi, indicating the participation of marine diatoms. In this situation, the BSi gave an excellent sign of the presence of siliceous phytoplankton associated with the values of chlorophyll- $a$, proving to be an excellent indicator of bioprocesses in the region, corresponding to an important member of the silicon biogeochemical cycle. The LSi showed a different behavior than the other fractions of silicon, being more related to sediment resuspension process and interaction with the SPM than fluvial influence. In the stations more distant, a signal of not significant correlation of $\mathrm{BSi} /$ Chlorophyll- $a$ evidenced the participation of another actors, not siliceous contributing to primary production where parameters had characteristics values of oligotrophic waters, with the silicon fractions showing very low concentrations.

\section{ACKNOWLEDGEMENT}

The authors thank FAPESP for the support of the CARECOS Project n. 2011/50582-0, the team of the oceanographic vessel B/Pq Alpha Delphini, a vessel of Oceanographic Institute of the University of São Paulo (IOUSP) and to the team of Laboratory of Biogeochemistry 


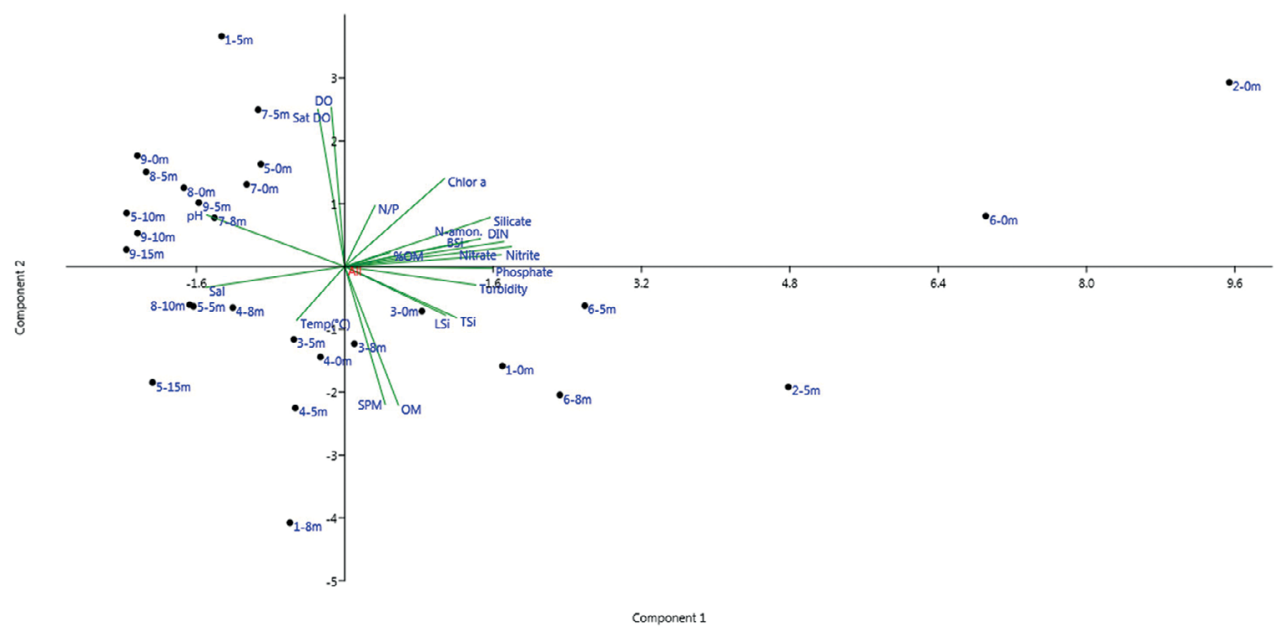

Figure 7. Data from Principal component analysis (PCA) of inorganic and organic variables of the Inner Sea coast of Fernando de Noronha Island - Pernambuco (Brazil). (A) Ordering of environmental variables, (B) ordering of samples (SPM=suspended particulate material, N-nitrite, N-nitrate, P-phosphate, Si-silicate, LSi=Lithogenic silicon, BSi=Biogenic silica; DOP=Dissolved Organic Phosphorus, DIN=Dissolved Inorganic Nitrogen, SPM=Suspended particulate matter, SPOM= Suspended particulate organic matter, $\mathrm{pH}, \mathrm{N}$-ammon. $=\mathrm{N}$-ammonium, $\mathrm{DO}=$ Dissolved oxygen, $\mathrm{Sal}=$ salinity, $\mathrm{T}=$ temperature, Turbidity, Chlor.=Chlorophyll-a obtained in March 2015.

of Nutrients, macronutrients and traces in the ocean (LABNUT-IOUSP) for the support in the chemical analysis.

\section{REFERENCES}

AMINOT, A. \& CHAUSSEPIED, M. 1983. Manuel des analyses chimiques en milieu marin, Brest, CNEXO

ANJOS, D. L., PASSAVANTE, J. Z. O., SILVA-CUNHA, M. G. G. \& HONORATO DA SILVA, M. 2012. Biomassa fitoplanctônica correlacionada aos fatores hidrológicos no estuário do rio Capibaribe (Recife, Pernambuco, Brasil). Tropical Oceanography, 40, 167-168.

ARAÚJO, M. C. B., SOUZA, S. T. S., CHAGAS, A. C. O.; BARBOSA, S. C. T. \& COSTA, M. F. 2007. Análise da ocupação urbana das praias de Pernambuco, Brasil. Revista da Gestão Costeira Integrada, 7, 97-104.

BASTOS, R. B., FEITOSA, F. A. N., KOENING, M. L. MACHADO, R. C. A. \& MUNIZ, K. 2011. Caracterização de uma zona costeira tropical (Ipojuca-Pernambuco-Brasil): produtividade fitoplanctônica e outras variáveis ambientais. Brazilian Journal of Aquatic Science and Technology, 15, 1-10.

BELL, R. G. 1994. Behaviour of dissolved silica, and estuarine/ coastal mixing and exchange processes at Tairua Harbour, New Zealand. New Zealand Journal of Marine and Freshwater Research, 28, 55-68.

BLANCHERD, S. F. 1988. Dissolved silica in the tidal Potomac River and Estuary. 1979-81 water years, Denver, United States Geological Survey water supply paper 2234-H.

BORGES, G. C. P., SILVA-CUNHA, M. G. G., SANTIAGO, M. F. \& LIMA, J. C. 2012. Comunidade fitoplanctônica e variáveis ambientais em área portuária, nordeste do Brasil. Tropical Oceanography, 40, 309-318.
BOYLE, E., COLLIER, R., DENGLER, A. T., EDMOND, J. M., NG, A. C. \& STALLARD, R. F. 1974. On the chemical mass-balance in estuaries. Geochimica et Cosmochimica Acta, 38, $1719-1728$.

BRYNER, F. M. M., FREITAS BARBOSA, A. M., PHILLIPINI DA SILVA, H. K. \& VIERA DE MELO, M. 2003. Behaviour of heavy metals in the estuarine area of the Capibaribe River in the Northeast of Brazil. Journal de Physique IV (France), 107, 221-225.

COSTA, O. S. 2007. Anthropogenic nutrient pollution of coral reefs in southern Bahia, Brazil. Brazilian Journal of Oceanography, 55, 265-279.

DEMASTER, D. J. 1981. The supply and accumulation of silica in the marine environment. Geochimica et Cosmochimica Acta, 45, 1715-1732.

FIGUEIREDO, M. A. O., HORTA, P. A., PEDRINI, A. G. \& NUNES, J. M. C. 2008. Benthic marine algae of the coral reef of Brazil: a literature review. Oecologia Brasiliensis, 12, 258-269.

FIRME, G. F., RUE, E. L., WEEKS, D. A., BRULAND, K. W. \& HUTCHINS, D. A. 2003. Spatial and temporal variability in phytoplankton iron limitation along the California coast and consequences for $\mathrm{Si}, \mathrm{N}$ and $\mathrm{C}$ biogeochemistry. Global Biogeochemical Cycle, 17, 1016-1029.

FONSECA, R. S., PASSAVANTE, J. Z. O., MARANHÃO, G. M. B. \& MUNIZ, K. 2002. Ecossistema recifal da praia de Porto de Galinhas (Ipojuca, Pernambuco): biomassa fitoplanctônica e hidrologia. Boletim Tecnico Cientifico do Cepene, 10, 9-26.

GUENTHER, M., ARAÚJO, M., FLORES-MONTES, M., GONZALEZ-RODRIGUEZ, E. \& NEUMANN-LEITÃO, S. 2015. Eutrophication effects on phytoplankton size-fractioned biomass and production at a tropical estuary. Marine Pollution Bulletin, 91, 537-547. 
GRASSHOFF, K., EHRHARDT, M. \& KREMLING, K. 1983. Methods of seawater analysis, $2^{\text {nd }} \mathrm{ed}$, Weinhein, Verlag Chemie.

HAY, W. W. 2004. Carbonate fluxes and calcareous nannoplankton. In: THIERSTEIN, H. R. \& YOUNG, J. R. (Eds.) Coccolithophores - From Molecular Processes to Global Impact. Berlin Heidelberg: Springer-Verlag.

HELDER, W., DE VRIES, R. T. P. \& RUTGERS VAN DER LOEFF, M. M. 1983. Behavior of Nitrogen Nutrients and Dissolved Silica in the Ems-Dollard Estuary. Canadian Journal of Fisheries and Aquatic Sciences, 40, 188-200.

HONJO, S. 1976. Coccoliths: Production, transportation and sedimentation. Marine Micropaleontology, 1, 65-79.

HUNT, D. T. E. \& FOSTER, P. P. 1977. Studies of the mixing of coastal waters in Liverpool Bay using dissolved silicate as a tracer. Water Research, 11, 465-470.

KOENING, M. L. \& MACÊDO, S. J. 1999. Hydrology and phytoplankton community structure at Itamaracá-Pernambuco (Northeast Brazil). Brazilian Archives of Biology and Technology, 42.

LISS, P. S. 1976. Conservative and non-conservative behavior of dissolved constituent during estuarine mixing. In: BURTON, J. D. \& LISS, P. S. (eds.) Estuarine Chemistry. London: Academic Press.

LIU, S. M., ZHANG, J. \& LI, R. X. 2005. Ecological significance of biogenic silica in the East China Sea. Marine Ecology Progress Series, 290, 15-25.

MACIEL, D. C., SOUZA, J. R. B., TANIGUCHI, S., BÍCEGO, M. C. \& ZANARDI-LAMARDO, E. 2015. Sources and distribution of polycyclic aromatic hydrocarbons in a an urbanized tropical estuary and adjacent shelf, Northeast of Brazil. Marine Pollution Bulletim, 101, 429-433. DOI: http://dx.doi. org/10.1016/j.marpolbul.2015.09.051.

MARTINS, S. E. M., BARCELLOS, R. L., FLORES-MONTES, M. J. \& FRANÇA, E. J. 2016. Depositional evolution in a estuarine lagoonal system under a port influence in Northeastern Brazil. Journal of Coastal Research, 75, 84-88.

MEDEIROS, C. \& KJERFVE, B. 1993. Hydrology of a tropical estuarine system: Itamaracá, Brazil. Estuarine, Coastal and Shelf Science, 36, 495-515.

RAGUENEAU, O., SAVOYE, N., AMO, Y. D., COTTON, J., TARDIVEAU, B. \& LEYNAERT, A. 2005. A new method for the measurement of biogenic silica in suspended matter of coastal waters: using Si:Al ratios to correct for the mineral interference. Continental Shelf Research, 25, 697-710.

RAGUENEAU, O. \& TRÉGUER, P. 1994. Determination of biogenic silica in coastal waters: applicability and limits of the alkaline digestion method. Marine Chemistry, 45, 43-51.

ROLLNIC, M., MEDEIROS, C. \& FREITAS, I. 2011. Coastal circulation along the southern metropolitan region of Recife, northeastern Brazil. Journal of Coastal Research, 64, 135138.
ROMERO, O. E., FISCHER, G., LANGE, C. B. \& WEFER, G. 1999. Siliceous phytoplankton of the western equatorial Atlantic: sediment traps and surface sediments. Deep Sea Research Part II: Topical Studies in Oceanography, 47, 1939-1959.

ROST, B. \& RIEBSELL, U. 2004. Coccolithophore calcification and the biological pump: response to environmental changes. In: THIERSTEIN, H. R. \& YOUNG, J. R. (eds.) Coccolithophores From Molecular Processes to Global Impact. Berlin Heidelberg: Springer-Verlag.

SÁNCHEZ, G. E., PANTOJA, S., LANGE, C. B., GONZÁLEZ, H. E. \& DANERI, G. 2008. Seasonal changes in particulate biogenic and lithogenic silica in the upwelling system of Concépcion $\left(\sim 36^{\circ} \mathrm{S}\right)$ Chile, and their relationship to fluctuations in marine productivity and continental input. Continental Shelf Research, 28, 2594-2600.

SANTIAGO, M. F., SILVA-CUNHA, M. G. G., NEUMMAN-LEITÃO, S., COSTA, K. M. P., PALMEIRA, G. C. B., PORTO NETO, F. F. \& NUNES, F. S. 2010. Phytoplankton dynamics in a highly eutrophic estuary in tropical Brazil. Brazilian Journal of Oceanography, 58, 185-205.

SCHETTINI, C. A. F., PAIVA, B. P., BATISTA, R. A. L., OLIVEIRA FILHO, J. C. \& TRUCCOLO, E. C. 2016. Observation of an estuarine turbidity maximum in the highly impacted Capibaribe estuary, Brazil. Brazilian Journal of Oceanography. 64, 185-190.

SHIPE, R. F. \& BRZEZINSKI, M. A. 2001. A time series study of silica production and flux in an eastern boundary region: Santa Barbara Basin, California. Global Biogeochemical Cycles, 15, 517-531.

SHIPE, R. F., CURTAZ, J., SUBRAMANIAN, A., CARPENTER, E. J. \& CAPONE, D. G. 2006. Diatom biomass and productivity in oceanic and plume-influenced waters of the western tropical Atlantic ocean. Deep Sea Research Part I: Oceanographic Research Papers, 53, 1320-1334.

SILVA, R. L., PEREIRA, S. M. B., OLIVEIRA, E. C. \& ESTON, V. R. 1987. Structure of a bed of Gracilaria spp. (Rhodophyta) in northeastern Brazil. Botanica Marina, 30, 517-523.

SOUZA, W. L. S. 2011. Produção de sedimentos na bacia hidrográfica do rio Capibaribe para zona costeira da região metropolitana do Recife. Dissertation. (MSc). Universidade Federal Rural de Pernambuco.

SHR - SECRETARIA DE RECURSOS HÍDRICOS. 2010. Plano hidroambiental da bacia hidrográfica do rio Capibaribe: resumo executivo e Projetos técnicos, Recife, SHR.

STRICKLAND, J. D. H. \& PARSONS, T. R. 1968. A practical handbook of seawater analyses, Ottawa, Fisheries Research Board of Canada.

TORRES, J., PEREIRA, S. M. B. \& YONESHIGUE-VALENTIN, Y. 2004. Ceramiaceae (Rhodophyta) de áreas recifais do estado de Pernambuco, Brasil. Hoehnea, 31, 201-212.

TRAVASSOS, R. K., FLORES MONTES, M. J., COSTA, B. V. M. \& SILVA JÚNIOR, J. M. 2016. The Influence of Urban Effluents on the Elemental C/N Ratio in a Tropical Coastal Area of Northeastern Brazil. Journal of Coastal Research, 75, 168-172. 